\title{
MASTER
}

\section{Interim Implementation Structure for Development of Performance Criteria and Test Standards for Photovoltaic Systems}

November 15, 1979

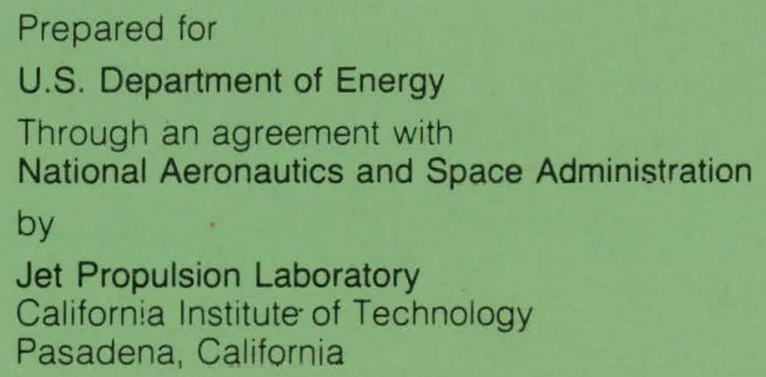




\section{DISCLAIMER}

This report was prepared as an account of work sponsored by an agency of the United States Government. Neither the United States Government nor any agency Thereof, nor any of their employees, makes any warranty, express or implied, or assumes any legal liability or responsibility for the accuracy, completeness, or usefulness of any information, apparatus, product, or process disclosed, or represents that its use would not infringe privately owned rights. Reference herein to any specific commercial product, process, or service by trade name, trademark, manufacturer, or otherwise does not necessarily constitute or imply its endorsement, recommendation, or favoring by the United States Government or any agency thereof. The views and opinions of authors expressed herein do not necessarily state or reflect those of the United States Government or any agency thereof. 


\section{DISCLAIMER}

Portions of this document may be illegible in electronic image products. Images are produced from the best available original document. 
5240-2

DOE/JPL-1012-35

Photovoltaics Program

Technology Development and Applications

Distribution Category UC-63b

Lead Center

\section{Interim Implementation Structure for Development of Performance Criteria and Test Standards for Photovoltaic Systems}

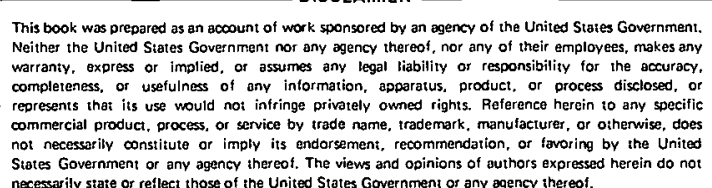

November 15,1979

\section{Prepared for}

U.S. Department of Energy

Through an agreement with

National Aeronautics and Space Administration

by

Jet Propulsion Laboratory

California Institute of Technology

Pasadena, California

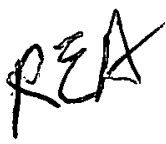


Prepared by the Jet Propulsion Laboratory, California Institute of Technology, for the U.S. Department of Energy through an agreement with the National Aeronautics and Space Administration.

Thls Itepuil w'às preparod af an arrnint if work sponsored by the United States Government. Neither the United States nul the United Etatos Department nf Energy, nor any of their employees, nor any of their contractors, subcontractors, or their employees, makes any warranty, express or implied, or assumes any legal liability or responsibility for the accuracy, completeness or usefulness of any information, apparatus, product or process disclosed, or represents that its use would not infringe privately owned rights. 


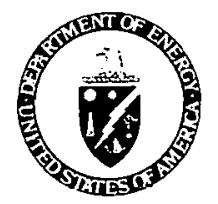

Department of Energy

Washington, D.C. 20585

\section{Dear}

The Solar Energy Research Institute (SERI), under contract to the Department of Energy, has prepared this Interim Implementation Structure for the Development of Performance Criteria and Test Standards (PC/TS) for Photovoltaic Systems. This document is being sent to all interested members of the photovoltaic and standards communities for their review and information.

This structure has been reviewed and approved by the PC/TS Project Coordinating Council, by the Photovoltaics Technology Development and Applications Lead Center and by the Photovoltaics Systems Branch of the Department of Energy. It supports, and is consistent with, the Photovoltaic Multi-Year Program PIan and with the National Photovoltaic Research, Development and Demonstration Act of 1978.

The philosophy of this implementation structure is that the consensus standards community must write whatever standards need to be established. In support of these groups, this project will provide basic information, methods and results to accelerate the consensus process.

The approach set forth recognizes the desirability and need to work closely with consensus standard writing organizations to provide uniform and consistent standards for use by the photovoltaic community. This document presents a procedure to develop necessary performance criteria and test methods and outlines a process by which these criteria and methods can be adopted or adapted by consensus standards groups.

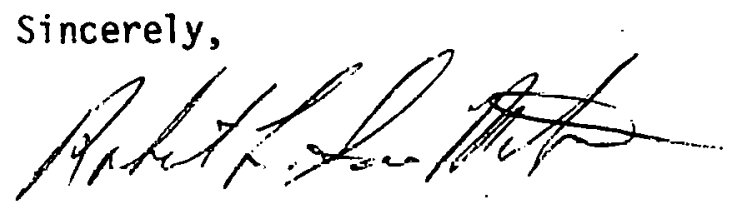

Robert L. San Martin, Director Division of Distributed Solar Technology 


\section{THIS PAGE \\ WAS INTENTIONALLY LEFT BLANK}




\begin{abstract}
This document presents an implementation structure for the near-term development of performance criteria and test methods for photovoltaic (PV) materials, components, subsystems, and systems. The approach is designed to be responsive to the Photovoltaic Research, Development and Demonstration Act of 1978 (PL-95-590).

The project is organized into four tasks: (1) establishment of performance criteria and the development of test methods; (2) development of laboratory accreditation/product certification guidelines; (3) development of validation methodologies; and (4) coordination of the quality assurance effort with consensus standards and code organizations. A schedule and milestones are presented for each task. The appendices provide a brief overview of standards and the standards development process.

The philosophy behind this project is to develop industry- and user-established performance criteria, test methods, and accreditation procedures which may then be referred to independent consensus standards organizations for the preparation of consensus standards. The emphasis in execution of this approach will be to develop uniform, fair performance criteria and tests and to avoid rigid, prescriptive criteria. Photovoltaics is an emerging technology; criteria written now must be able to accommodate devices and techniques not yet developed.
\end{abstract}




\section{THIS PAGE WAS INTENTIONALLY LEFT BLANK}


PREFACE

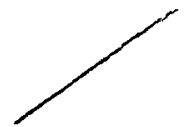

This report was prepared for the JPL Lead Center by SERI. Il was completed under cognizance of DOE Contract No. 77-C-01-4042 with SERI. Mr. R. V. Powell, JPL Subprogram Manager, Systems Engineering and Standards, is the responsible individual regarding subject matter. 


\section{THIS PAGE WAS INTENTIONALLY LEFT BLANK}




\section{FOREWORD}

This implementation structure describes an approach for developing performance criteria and test methods for photovoltaic systems. The project to develop and to implement this approach is an element of the Technology Development and Applications Section of the Photovoltaic Systems Branch, Division of Distributed Solar Technology, Department of Energy (DOE).

This project is conducted for DOE by the Quality Assurance and Standards Branch of the Commercialization Division. Branch Chief is Gary R. Nuss and Project Manager is Richard DeBlasio. Dr. Leonard Magid (DOE

Photovoltaic Systems Branch) provided counsel, guidance, and assistance during the preparation of this document and in the development of the implementation approach.

This implementation structure has been prepared to describe specific planned activities to be conducted by DOE in connection with the Photovoltaic Program. Although this document has been reviewed by DOE and represents current perceptions of the objectives to be achieved and strategies to be followed, some of the details described have not been subject to an in-depth review nor completely approved. Furthermore, budget and resource levels for fiscal years beyond the current year are planned only and are not an official commitment to this project. Consequently, the document should be considered a working document, subject to further revision as the project develops. 
THIS PAGE

WAS INTENTIONALLY

LEFT BLANK 


\section{TABLE OF CONTENTS}

Page

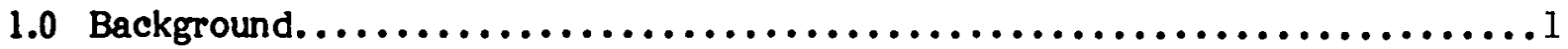

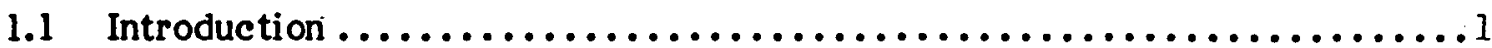

1.2 Scope and Objectives of the Performance Criteria and Test

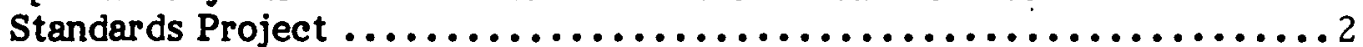

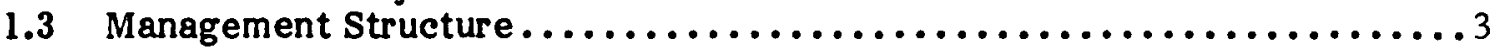

2.0 Task Descriptions $\ldots \ldots \ldots \ldots \ldots \ldots \ldots \ldots \ldots \ldots \ldots \ldots \ldots \ldots \ldots \ldots \ldots$

\subsection{Development of Performance Criteria and}

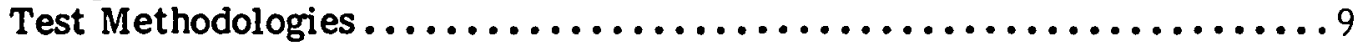

2.2 Development of Accreditation and Certification

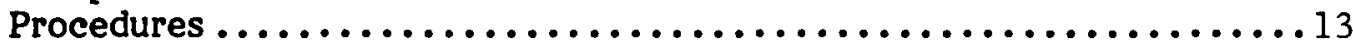

2.3 Development of Validation Methodologies .................... 15

2.4 Coordination of the Program with Standards and

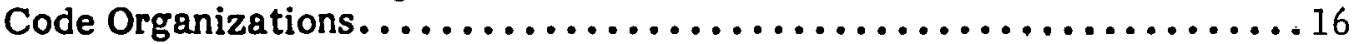

Áppendix A: Role and Purpose of Standards Development $\ldots \ldots \ldots \ldots \ldots \ldots \ldots \ldots$.

Appendix B: The Voluntary Consensus Standards Process ................ B-1

Appendix C: $\quad$ Glossary of Standards Terminology $\ldots \ldots \ldots \ldots \ldots \ldots \ldots \ldots \ldots \ldots$.

Appendix D: Members of the Coordinating Council $\ldots \ldots \ldots \ldots \ldots \ldots \ldots \ldots \ldots$.

Appendix E: Members of the Subcommittees $\ldots \ldots \ldots \ldots \ldots \ldots \ldots \ldots \ldots \ldots . \ldots \ldots$

Appendix F: Members of the Task Groups and the Task Group

Steering Committee ............................... 


\section{LIST OF FIGURES}

$\underline{\text { Page }}$

1-1 Schedule and Key Milestones............................4

1-2 Project Management Structure $\ldots \ldots \ldots \ldots \ldots \ldots \ldots \ldots \ldots \ldots \ldots \ldots \ldots$

\section{LIST OP TABLES}

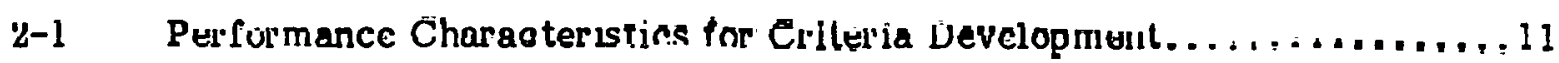

2-2 Potential Test Methodology Requirements

to Verify Criteria $\ldots \ldots \ldots \ldots \ldots \ldots \ldots \ldots \ldots \ldots \ldots \ldots \ldots \ldots \ldots \ldots$ 


\section{SECTION 1.0}

\section{BACKGROUND}

\subsection{INTRODUCTION}

\subsubsection{The National Photovoltaic Program}

The objective of the Department of Energy (DOE) Photovoltaic Program is to bring photovoltaic energy systems-via research, development, and demonstrations (RD\&D) aimed at achieving major cost reductions and market penetration-to the point at which they are able to supply a significant portion of the nation's energy requirements.*

Photovoltaic technology provides an inexhaustible and relatively nonpolluting energy source. Its technical feasibility has been a demonstrated fact for many years, but costs of systems currently being produced have confined their use to small-scale, remote applications. To achieve significant fuel displacement, photovoltaic systems must be able to replace electrical energy currently being supplied by electrical utility grids. Thus, the program must reduce system costs to a competitive level in grid-connected and total energy applications and at the same time resolve the technical, environmental, institutional, legal, and social issues involved in fostering widespread adoption of photovoltaic power systems.

The photovoltaic program strategy is to achieve major cost reductions-leading to competitive life-cycle costs-by aggressively pursuing advanced research and technology development. Real-world testing and eventual commercialization efforts also are required to effect large-scale transfer of laboratory accomplishments to the commercial arena.

The program, therefore, is directed toward the development of economically competitive, comm ercially available, photovoltaic power systems which provide safe and reliable energy for a wide range of applications. In particular, distributed, grid-connected, and total energy residential systems should be able to displace significant amounts of centrally generated electricity-first in the Southwest and later throughout most of the United States. Intermediate-size commercial, institutional, and industrial on-site systems can provide a similar option. Finally, utilities ultimately should be able to augment their generating capacity with larger-scale systems.

\subsubsection{Purpose of the Implementation Structure}

A major goal of this project is to obtain the assistance and guidance of industry, public interest groups, and professional standards-writing orgunizations early in the quality assurance (QA) effort. This plan is designed to provide a basis for the development of appropriate criteria, test methodologies, and accreditation/certification programs. These tasks are essential both for establishing a viable industry infrastructure and to

* According to the recently completed Solar Energy Domestic Policy Review, photovoltaics, in the "maximum practical case," can annually displace as much as 1.0 quad of primary fuel by the year 2000 , whereas in the "base case," 0.1 quad can be displaced in the year 2000 . 
enhance user confidence in photovoltaic systems. Performance criteria and test methodologies are among the tools necessary to ensure an appropriate level of quality and to reduce the perceived risk of use. However, photovoltaic technology is still very much in flux. Accordingly, this plan must be able to accommodate the entry of advanced technologies and cost improvements by design modification.

Various legislative mandates require the development of elements of a QA program. The Solar Photovoltaic Energy Research, Development and Demonstration Act of 1978 (PL-95-590) authorizes the Secretary of Energy to establish performance criteria for photovoltaic systems and components. The Act also calls for revisions of the criteria and development of product certification procedures as photovoltaic technology matures. In addition to the requirements of the National Photovoltaic Program, the Federal Photovoltaic Utilization Program calls for photovoltaic applications at government facilities. This implementation plan somplies with these legislative requirements.

\subsubsection{Content of the Implementation Structure}

A framework for photovoltaic performance criteria development is presented with recommendations for addressing initial priorities. These include: terminology and definitions; identification of performance characteristics and measurement methods for their verification; and safety requirements. This document does not detail all of the speciflc elements of these priorities; rather, it indicates initial areas of activity.

The plan outlines tasks and presents a schedule for achieving project goals. The criteria and test methods developed in this project.can then be referred to consensus standards organizations for adoption or adaptation as deemed appropriate. Background information is provided in the appendices on the role and purpose of standards and the standards development process, as well as an overview of the general types of standards promulgated by the voluntary consensus standards process.

\subsection{SCOPE AND OBJECTIVES OF THE PIOTOVOLTAIC PERFORMANCE CRITERIA AND TEST STANDARDS PROJECT}

\subsubsection{Scope}

The broad scope of the Solar Energy Research Institute (SERI) Quality Assurance and Standards Development Program is to develop and to promote the use of performance criteria and test methodologies which will loster the widespread use of all solar energy conversion systems in their appropriate applications. Within this program, SERI is managing the DOE Photovoltaic Performance Criteria and Test Standards project.

\subsubsection{Objectives}

\subsubsection{Overan Objective}

The overall objective of the Photovoltaic Performance Criteria and Test Standards (PC/TS) project is to stimulate the development and adoption of industry-established material, component, subsystem, and system performance criteria and standards for the design, application, and operation of reliable and safe photovoltaic power systems. 
This objective addresses the need for performance criteria and test standards. It is recognized that a traditional institutional framework for the development of consensus standards exists. It is also recognized that this framework usually operates in neither an anticipatory nor a speedy manner. When carefully designed, acceleration of the standards-setting process can facilitate the widespread commercialization of photovoltaic technology.

This plan presents objectives and tasks for FY79 through FY82 (see Fig. 1-1 for a schedule of milestones). Specific tasks beyond FY82 will probably be directed at evaluation and validation of tests through field experience.

\subsubsection{General Objectives}

- Support and assist in the development of a comprehensive body of performance criteria and, ultimately, standards for performance, reliability, and safety for photovol taic (PV) energy conversion systems.

- Develop and assist implementation of criteria and procedures for the accreditation of laboratories to test photovoltaics.

- Develop and assist implementation of certification criteria and procedures for photovol taics.

- Develop and implement validation mechanisms for monitoring criteria and test methods.

- Coordinate DOE/SERI quality assurance activities for PV, internally and externally, with national and regional consensus standards and code organizations.

These objectives represent the desired project accomplishments.* To achieve these objectives, various elements of the DOE photovoltaic program, the photovoltaic industry, public interest organizations, consensus standards groups, and others will combine their resources and talents. SERI's project responsibility is to coordinate these contributions and to convene these interests for purposes of coordination, review, and consensus. UItimately, implementation of these nonfederal processes must lie with nonfederal organizations and associations.

\subsection{MANAGEMENT STRUCTURE}

\subsubsection{Introduetion}

SERI began management of this project in 1978 with the establishment of a Conrdinating Council (Fig. 1-2). The Council met tliree times in 1978. Its membership (Appendix D) includes representatives from industry, voluntary consensus standards groups, public interest groups, independent test laboratories, prime contractors in the DOE PV program, and SERI. The Council has made significant progress toward developing performance criteria by:

*Specific goals to support the general objectives of the project are presented in the separate task discussions (Sections $2.1-2.4$ ). 


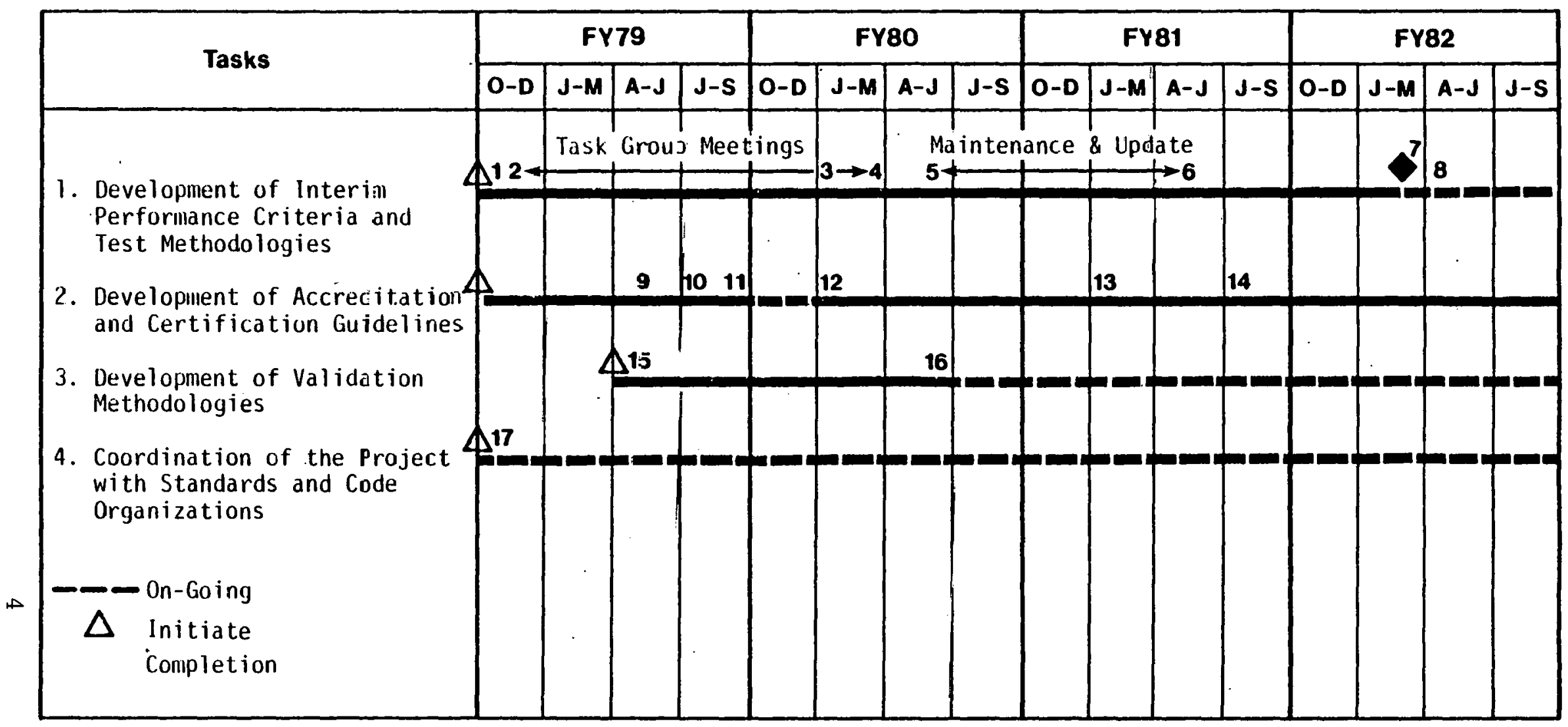

\section{KEY MILESTONES}

1. Semi-Annual Review and public presentation of plan.

2. Task Groups organized \& IPC initiated.

3. Initiate Round-Robin testing, if feasible, based on Task Group recominendations.

4. Initiate IPC review process.

5. IPC issued.

6. Final Performance Criteria (PC) Document issued for review.

7. PC Document revised and finalized.

8. Maintenance Mode.

9. Completion of Test Laboratory I iventory.

10. Draft report on accreditation/cartificatiof program guidelines.
11. Final report on guijelines and recommendations for accreditation/certification of PV systems.

12. Initiate subcontract procurement to design \& plan implementation of accreditation/certification programs in applications where required.

13. Report on design and implementation plan for accreditation/certification prograns.

14. Implementation of private sector accreditation and certification proçrams as required.

15. Initiate developmert of validation methodologies.

16. Evaluate test methids and IPC contingent upon field data base (Continuing effort).

17. Coordination with concensus standards and code organizatioris to $e^{-f e c t}$ transfer of criteria and tests (Continuing effort). 
Structure

DOE PV

Systems

Branch

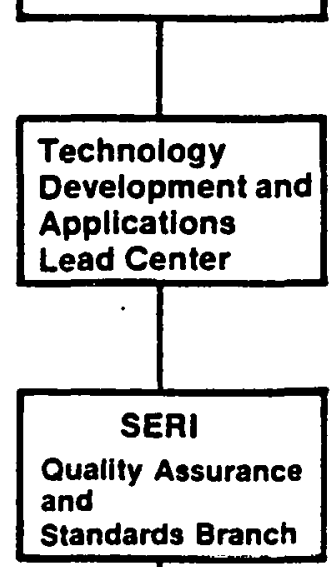

Technology

Development and

Applications

Apad Center
Responsibilities

.... Goal-setting

.... Program Management

.... Program Coordination

.... Project Manager

\section{Coordinating} Council

.... Guidance

.... Coordination

.... Recommendations

.... Review

Task Group Coordination

Task Group

Steering

Committee

.... IPC Integration
Task Group 1

PV Subsystem
Task Group 2

Power

Conditioning, and

Controls, Storage.

Cabling
Task Group 3

Systems
.... Criteria Development

.... Test Method Identification

.... Test Development Priorities

Figure 1-2. Management Structure 
- Identifying the systems hierarchy of flat-plate and concentrator systems;

- Defining elements of the PV subsystem; and

- Identifying performance criteria to be measured, priorities in test methodology development, and organizational resources and responsibilities for development.

During 1978 five subcommittees (Appendix E) were convened to support the Council:

- PV Performance Criteria (now PV subsystems),

- Storage,

- Power Conditioning and Control,

- Safety, and

- Reliability and Durability.

The subcommittees provided additional expertise in their respective areas and identified needs, priorities, and resources.

A steering committee made up of key program and project personnel will oversee the development of performance criteria and the test methods to support them. The Steering Committee will work through three task groups:

- Task Group No. 1 on the photovoltaic subsystem;

- Task Group No. 2 on other subsystems (power conditioning, controls, storage, and cabling); and

- Task Group No. 3 on total systems.

One activity within this project is the development of an Interim Performance Criteria (IPC) document and its updates and revisions. This document will form the basis for other activities and tasks within the project. The task groups will develop criteria and will prepare drafts of the IPC document. The task group steering committee wlll integrate these activities and products and will coordinate the review process through the subcommittees and the Coordinating Council.

\subsubsection{The Role of the DOE Program Office and the Technology Development Program Lead Center}

The role of the DOE Photovoltaic Systems Branch is to establish, maintain, and manage the achievement of the goals of the National Photovoltaic Program. The goals are Integrated into and coordinated with the varied projects and tasks within the total PV Program.

The Photovoltaic Systems Branch manages its responsibility for the National Photovoltaic Program through two field organizations. The Solar Energy Research Institute has been assigned responsibility as Lead Center for Advanced Research and Development. NASA's Jet Propulsion Laboratory (JPL) is the Lead Center for Technology Development and Applications (TDA). The PC/TS project lies within the Systems Engineering and Standards element of JPL's Lead Center responsibilities. 


\subsubsection{The Role of SERI}

SERI manages the Performance Criteria and Test Standards Project of the National Photovoltaic Program. The SERI project team will translate the goals of the project into specific tasks and will manage the resources to accomplish these tasks.

\subsubsection{The Role of the Coordinating Council}

The Coordinating Council acts as an advisor and reviewer to the project team. The Council will identify, review, and recommend specific needs, priorities, and timeframes for the project. The results of each task group's efforts will be reviewed by the Coordinating Council. The project team relies on the broad areas of interest represented on the Coordinating Council to discern unmet needs, to revise priorities, and to review the tasks' design and objectives.

In this role, the Coordinating Council has been assisted by subcommittees. These subcommittees will continue to operate on an ad hoc basis to address specific areas of criteria development. The subcommittees are currently organized as described in the introduction to this section. In 1978, the subcommittees:

- Reviewed terminology and definitions;

- Identified performance criteria to be measured;

- Identified needs for, and the status of, test methodologies;

- Established initial priorities; and

- Identified resources for each subcommittee area.

The subcommittees will be convened at the discretion of the Coordinating Council and the SERI project team. The subcommittees are expected to serve an important role in the review process for the IPC Document.

\subsubsection{The Role of the Task Group Steering Committee (TGSC)}

This Task Group Steering Committee provides coordination and synthesis functions, implementing the recommendations of the Coordinating Council through the task groups. Its main responsibility is to oversee development of performance criteria and test methods. The group is comprised of members of the SERI project team, an industry representative, the DOE program office, the TDA Lead Center, the National Bureau of Standards, and the three task group leaders-one each from Jet Propulsion Laboratory (JPL), Sandia Laboratories-Albuquerque (SLA), and MIT Lincoln Laboratories (MIT/LL). In general, the TGSC will:

- Integrate the output of the three Task Groups into an IPC document;

- Establish priorities to develop, evaluate, refine, and verify test methodology;

- Oversee the preparation of a measurement techniques appendix for the IPC document;

- Identify priorities for and establish the means to develop new test methods; and 
- Oversee the preparation of guidelines and recommendations for developing (and later implementing) accreditation of laboratories to test photovoltaic systems and components and for certification of PV equipment and products.

\subsubsection{The Role of the Task Groups}

Chief among the responsibilities of the task groups is to complete assignments as prescribed by the Task Group Steering Committee. The task groups are small, technically oriented, and membership comprises many interest areas. Each task group will address performance, safety, reliability, and durability. The task groups are:

1. Photovoltaic Subsystem (JPL)-which includes the array field, arrays (including concentrator, receiver, and tracker for PV concentrator arrays), panels, modules, and solar cclles

2. Other Subsystems (MIT/Lincoln Laboratory)-which includes power conditioning, controls, storage and cabling; and

3. Total Systems (Sandia Laboratories-Albuquerque).

\subsubsection{Summary}

The management structure of the project has been designed to ensure communication and cooperation among many interest areas in photovoltaics. This organization will permit feedback and validation as performance criteria and test methodologies are developed. Each group has been apprised of its charge and responsibllities, both of which may continue to evolve as the project matures. 


\section{SECTION 2.0}

TASK DESCRIPTIONS

\subsection{DEVELOPMENT OP PERFORMANCE CRITERIA AND TEST METHODOLOGIES (TASK ONE)}

\subsubsection{Introchuetion}

Photovoltaic systems and their applications will require a strong effort in quality assurance. Life-cycle costs are significantly influenced by maintenance costs and by benefits lost in the case of failure. Performance criteria and test methodologies are essential factors in design, production, marketing, and operation of a solar industry. They are vital for the protection of users (consumers), in promoting marketplace confidence, for comparing performance of different devices, and for ensuring reliable systems.

\subsubsection{Scope and Objectives}

The broad objective of this task is the identification, development, and promulgation of performance criteria and test methodologies for photovoltaic applications. Initial concentration will be on dispersed applications. Emphasis also will be placed on the application of technical resources from the entire photovoltaic community-producers, test laboratories, and DOE PV project teams-to develop new test methods that are necessary to support the IPC document. Specific objectives are:

- FY79-to develop interim performance criteria and test methodologies for dispersed applications. For this year, dialogue between the project and the voluntary consensus community will be established through overlapping participation of project team members and consensus group members. Maintaining this dialogue with national and international groups is a short-and long-term objective.

- FY80-to publish and to refine the IPC document, an effort which will continue in subsequent years.

- FY81-to revise the IPC document and to publish the Performance Criteria (PC) Document.

- FY82-to continue refining the PC Document as required. Continuation of the transfer of its elements to consensus standards organizations is anticipated as the dialogue between this effort and the voluntary consensus community expands, and this activity will be coordinated with international standards development organizations as well.

\subsubsection{Approach}

The SERI management structure (see Section 1.2 and Fig. 1-2) describes each organizational element and its responsibilities. These elements cover the range of photovoltaic interest areas, and each has a particular, active role in the IPC document development.

Task groups 1, 2, and 3 will address performance and safety criteria and criteria verification for specific applications. Verification will include techniques to measure perform- 
ance and safety characteristics. Reliability and durability characteristics will be included in both performance and safety criteria. Safety criteria also will include environmental hazards associated with the installation and use of PV energy systems. The IPC document may recognize but will not address environmental hazards with respect to the siting of PV systems.

The Coordinating Council (in the case of PV subsystems) and the subcommittees have identified particular performance characteristics that must be examined for development of performance criteria (Table 2-1) and have identified some of the test methods to verify these performance characteristics (Table 2-2).

The task groups' approach for addressing these characteristics (as well as others) will be iterative; that is, they will develop general criteria in their respective areas and then will adapt these general criteria for specific applications-residential, remote, standalone, etc. Each element of the PV system will be lookod at separately with respect to several performance attributes-mechanical, electrical, optical, structural, etc. Not all such studies will result in criteria statements, and not all criteria statements will require test measurements for verification. This Iterative approach, however, does provide a logical, comprehensive methodology to cover all aspects of performance and.safety.

A critical part of each task group's assignment will be to determine the minimum number of criteria and tests required to characterize PV systems. Development of unnecessary information and unnecessary testing are to be avoided.

In support of Task Groups 1, 2, and 3, the National Bureau of Standards is under subcontract to SERI to provide the following services:

- Review of the IPC document for completeness and consistency and for technical aspects in which NBS has expertise;

- Prepare a measurement techniques appendix of test methods for verifying performunese crilteria;

- Ald In eslublisling priorities for dovoloping, ovaluating, refining, and verifying test methodologies for PV performance characteristics; and

- Develop a protocol (outline guide) for test method draf ts to facilitate transfer to standards writing organizations.

It should be noted that the IPC document will be a constantly evolving compendium of performance and safety guidelines that will be evaluated and updated periodically.

The anticipated schedule of events for IPC development is as follows:* For FY79-FY80, the following schedule of activities has been planned.

*This schedule may be accelerated, in which case the periods of time for individual review elements will remain the same, but the initiation of the review process will be earlier. 


\section{Table 2-1. Performance Characteristics for Criteria Development}

\begin{tabular}{|c|c|c|c|c|}
\hline \multicolumn{4}{|c|}{ Functional Performance Characteristics } & \multirow{2}{*}{$\begin{array}{l}\text { Reliability- } \\
\text { Durability } \\
\text { Characteristics }\end{array}$} \\
\hline Array Field & Storage & $\begin{array}{c}\text { Power } \\
\text { Conditioning }\end{array}$ & Controls & \\
\hline $\begin{array}{l}\text { ARRAY } \\
\text { - Energy/Power Efiliciency } \\
\text { - Concenirator Acceptance } \\
\text { Angle }\end{array}$ & \multirow{4}{*}{$\begin{array}{l}\text { - Stzing } \\
\text { • Intertace and } \\
\text { Compatiblity } \\
\text { - Installation } \\
\text { - Protection } \\
\text { - Operation and } \\
\text { Malntenance }\end{array}$} & \multirow{4}{*}{ 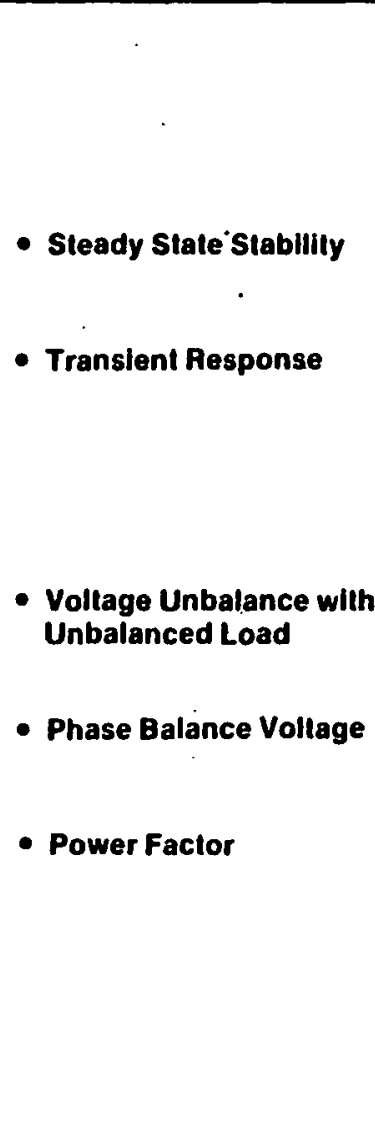 } & \multirow{4}{*}{$\begin{array}{l}\text { - Maxlmum Power } \\
\text { Tracking } \\
\text { - Manual Control } \\
\text { - Power Management } \\
\text { - Remole Control }\end{array}$} & \multirow{4}{*}{ 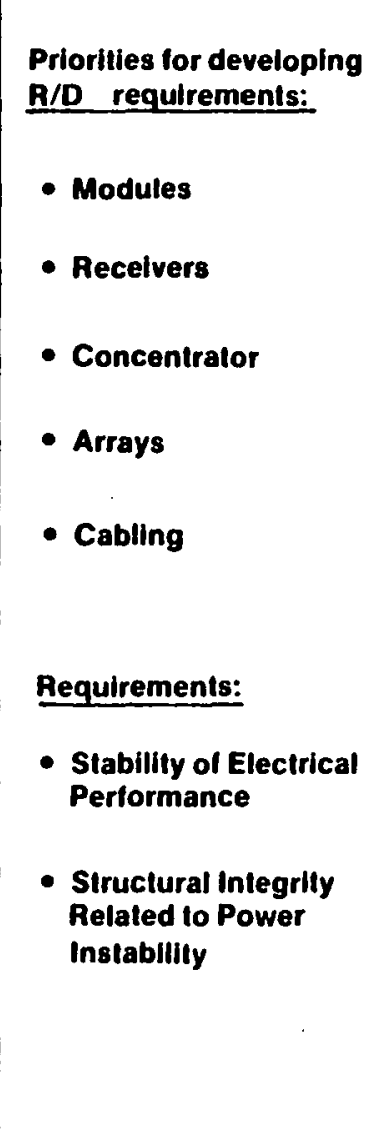 } \\
\hline $\begin{array}{l}\text { MODULE } \\
\begin{array}{l}\text { - I-V Concentrator } \\
\text { EAliciencry } \\
\text { - Acceptance Angle }\end{array}\end{array}$ & & & & \\
\hline $\begin{array}{l}\text { CONCENTRATOR } \\
\text { CELLASSEMBLY } \\
\text {-1-VIInsolation Dependence } \\
\text { - Entiliciency }\end{array}$ & & & & \\
\hline $\begin{array}{l}\frac{\text { CELL }}{\text { - Temperalure Co-Ellicient }} \\
\text { - Insolation Dependence }\end{array}$ & & & & \\
\hline
\end{tabular}




\section{Table 2-2. Potential Test Methodology Requirements to Verify Criteria}

\begin{tabular}{|c|c|c|c|c|}
\hline \multicolumn{4}{|c|}{ Methods for Functional Performance Criteria } & \multirow{2}{*}{$\begin{array}{l}\text { Methods for } \\
\text { Reliability- } \\
\text { Durability Criteria }\end{array}$} \\
\hline $\begin{array}{l}\text { Photovoltaic } \\
\text { Subsystems }\end{array}$ & Storage & $\begin{array}{c}\text { Power } \\
\text { Conditioning }\end{array}$ & Controls & \\
\hline $\begin{array}{l}\text { Measurement Methods for } \\
\text { - I-V relationship } \\
\text { - Temperalure Co-efficie it } \\
\text { - Insolation Dependence } \\
\text { - Spectral Response } \\
\text { - Acceptance Angle } \\
\text { - Voltage } \\
\text { - Energy } \\
\text { - Concentrator Rallo } \\
\text { - Insolation Vollage } \\
\text { - Elliciency } \\
\text { - Shunt Resistance } \\
\text { - Loading } \\
\text { - Stagnation Temperature } \\
\text { - Nominal Cooling } \\
\text { Temperalure } \\
\text { - Maximum Cooling } \\
\text { Temperature } \\
\text { - Soiling } \\
\text { - Mechanical Contiguraaiions }\end{array}$ & $\begin{array}{l}\text { Measurement Methods for: } \\
\text { - Acceptance Tests } \\
\text { - Periormance } \\
\text { - Replacement Needs } \\
\text { - Qualification } \\
\text { - Interiace Acceptability } \\
\text { Compatibilily } \\
\text { - Design Verification }\end{array}$ & $\begin{array}{l}\text { Measurement Methods for } \\
\text { - Regulation } \\
\text { - Steady State Slability } \\
\text { - Transient Response } \\
\text { - Wave Form } \\
\text { - Voltage Unbalance will } \\
\text { Unbalance Load } \\
\text { - Phase Balance Vollage } \\
\text { - Power Factor }\end{array}$ & $\begin{array}{l}\text { Measurement MEthods lor: } \\
\text { - Maximum Porrer } \\
\text { Tracking } \\
\text { - Manual Control } \\
\text { - Power Marajement }\end{array}$ & $\begin{array}{l}\text { Measurement Methods for } \\
\text { Effecls of: } \\
\text { - Electromagnelic Fields } \\
\text { - Almospheric } \\
\text { - Air Temperature } \\
\text { - Water Vapor } \\
\text { - Pressiure } \\
\text { - Humidity } \\
\text { - Preclpilalion } \\
\text { - Wind } \\
\text { - Contaminants } \\
\text { - Solar Occlusion } \\
\text { - Flammability } \\
\text { - Mechanical Loading }\end{array}$ \\
\hline
\end{tabular}


Date

November 7-9, 1978

December 1978

December, April, June,

August, November, 1979

January, March, April, May, June, July, August, September

October, November, 1979

Spring, Fall 1979

January 1980

February 1980

April 1980

June 1980
Activity

PV Semiannual Review and public presentation of plan

Task Groups organized and interim performance criteria activity initiated

Task Group Steering Committee Meetings (scheduled by SERI)

Task Group Meetings

(scheduled by Task Group

Coordinators)

TGSC review for the Coordinating Council (scheduled by SERI)

Subcommittee review begins

Coordinating Council review begins

Public Workshop on IPC document

Publish IPC document

\subsection{DEVELOPMENT OF ACCREDITATION AND CERTIPICATION PROCEDURES (TASK TWO)}

\subsubsection{Introduction}

The development of an industry capable of producing, designing, and installing photovoltaic systems that meet performance and lifetime criteria will require-for specific applications-the accreditation of third-party independent testing laboratories qualified to certify photovoltaic products and systems. This task is directed at developing and implementing procedures for both laboratory accreditation and product/system certification. It is the aim of this task that these programs and procedures be designed, created, and implemented by independent, private organizations. Initially, this task is planned for FY79 through FY82, although project support may extend beyond this time if necessary.

\subsubsection{Scope and Objectives}

The specific objectives of this task are: to ensure the protection of consumers and users; to promote confidence in photovoltaic products and systems; to support industry through the development of a consistent set of requirements; and to ensure the establishment of flexible programs that can accommodate future technological innovation. 


\subsubsection{Approach}

Specific task elements are:

- For FY79

- Comprehensive review of programs and literature on accreditation/ certification;

- Development of guidelines as to the direction and management of an accreditation program;

- Identification of independent third-party testing laboratories capable of testing performance criteria for photovoltaic products and systems; and

- Dcvolopment of guidèines for direclling und mainaging a eertification program.

- For FY80: Manage, under subcontract, a task to design programs and to develop an implementation plan for programs for the accreditation of testing laboratories and for certification of photovoltaic components and systems in appropriate applications.

- For FY81: Implementation of private sector àcereditation and cerlification programs as required.

This task for FY79 will initiate accreditation/certification activities by reviewing the literature on existing programs from other technologies, including solar heating and cooling. A document will be prepared in FY80 outlining conclusions and recommendations as to the direction and management of these programs.

Through subcontract management, the project will guide development of laboratory accreditation procedures which are intended to ensure both technical and procedural credibility. In the implementation stages, the project team will provide managerial, technical, and administrative support. The program to be developed should be structured similarly to traditional laboratory accreditation programs for other technologies. SERI and the other project resources will lend support as required to the laboratory accreditation program after it is implemented.

The project will support development of an industry program for certifying products and systems through a subcontract program for design and implementation. This program needs to be structured to maximize consumer confidence in photovoltaic systems and to aid industry development through the use of a consistent set of requirements for photovoltaics. This project support will be effected through the continuing development and evaluation of test methodologies.

The development of test methodologies and performance criteria in Task One will lead to standards that can be referenced in laboratory accreditation and product certification programs. These programs must be carefully designed to make maximum use of the experience gained from other technologies, and it is the intent of this project that these programs be implemented by independent private organizations. 


\subsection{DEVELOPMENT OF VALIDATION METHODOLOGIES (TASK THREE)}

\subsubsection{Introduction}

Most applications for photovoltaics will demand a high degree of reliability. Photovoltaic energy systems must compete in the marketplace with conventional systems of proven reliability in which the user has an established degree of confidence. The assurance of reliability and durability is a crucial part of the entire technology development program.

Methods for extracting, measuring, and evaluating performance data are essential in determining whether PV systems are reliable. This determination can be made by use of well-planned testing programs. For specific tests-such as accelerated and real-life tests-there is a need to validate both the tests and their results when no supporting information is available.

The guidelines for data collection from photovoltaic field tests and applications must promote consistent data acquisition techniques. The use for which the data are being developed must be determined before data collection begins, as well as the method for analyzing data and determining its validity.

In some cases, analysis methodology may be available for photovoltaic applications from other technologies.. Where there is no known technique, it will be necessary to develop and to test new techniques. Where there are known and appropriate techniques, testing will be required to validate applicability.

The long-range objective of this task is the development and implementation of validation mechanisms for monitoring photovoltaic energy system performance. This task will require data collection to verify the adequacy of the testing methods. Field tests should yield data to generate confidence in accelerated tests. This information then can become part of the foundation for American National Standards for photovoltaics.

\subsubsection{Scope and Objectives}

The objective of this task is to develop and to implement data analyses and validation methodologies for monitoring quality assurance for photovoltaic systems. Specific objectives for FY79 are to begin formulating general methods for reliability analysis and to begin determining data needs and acquisition plans. In subsequent years, data will be correlated with test results to determine the validity of test methodologies.

\subsubsection{Approach}

DOE Field Test and Applications (FTA) projects* will provide the vehicle for gathering data on performance, reliability/durability, and safety. As photovoltaics approach commercialization, it will be necessary to have reliable information from which to predict

*These projects can include those in current flat-plate and concentrator Program Research and Development Announcements (PRUAs) as well as others. 
system performance and expected rates of failure. This task will coordinate the development of evaluation methodologies for validating tests, guidelines, and standards.

This project also will coordinate tasks for collecting data from field tests and applications, specifically with respect to quality assurance. Such data will be used to measure the accuracy of accelerated tests as compared to real-life tests.

This task will lead to the validation of test methodologies developed within this project as well as from other sources. Data collection will yield information for analyzing potential system, subsystem, component, and material failures and the means to anticipate and to avoid such failures. It is a multiyear process; the collection and analysis of data will extend beyond the time period covered in this plan.

The following specific activities are planned:

- Data Development: Field Tests and Applications (FTA) provide an opportunity for the collection of data, data analysis, and quality assurance validation. The SERI project team will participate in the planning, design, and coordination of FTA projects. Sandia Laboratories, Albuquerque (SLA) has already established plans for data acquisition and analysis for the 1978 PRDAs. MIT Lincoln Laboratories and NASA Lewis Research Center also have responsibility for FTA projects; the PC/TS project team will work with each of these groups to develop measurements and data for reliability analysis and for validation of test methods.

- Review of Reliability Analysis Methodology: A review will be made of existing analysis techniques for application to photovoltaic systems and components.

- Validation of Test Methodologies: The project team will begin a program for ensuring the validation of test methodologies developed in various organizations.

It should be noted that the approach just described also will lend itself to the needs of the research and technology development programs. For example, data collection from field tests or applications can be used as input in evaluating new reliability models for. systems, subsystems, components, and materlals. This approach will enable the researcher to determine whether the models and accelerated data can predict materials, component, subsystem, and system reliability accurately. This approach in most cases will be theoretical and will support the reliability engineering methodologies.

\subsection{CONRDINATION WITH STANDARDS AND CODE ORGANZATIONS (TASK FOUR)}

\subsubsection{Introduction}

This project embraces the concept of voluntary consensus standards. It recognizes the need to rely upon the traditional institutional framework of the voluntary consensus standards community for standards writing and for revisions to building codes. This institutional framework provides the benefits of time-proven effectiveness, representation of a balance of interests, adherence to que process, and assumption of a major portion of the costs by the private sector.

Standards development in the United States has been structured to respond to needs in existing technologies whereas anticipatory standards development is needed for the accelerated commercialization of photovoltaic systems. Such standards, if carefully drawn, can stimulate new technology and guide its development. 
This project will provide resources (technical assistance, data, draft standards) for national and international standards development and for their implementation in building codes. For example, an important objective of DOE/SERI photovoltaic performance criteria development is to bring together representatives of standards organizations, photovoltaic R\&D, manufacturing, and user communities. SERI will support efforts to establish standards and will work with groups having responsibility for writing standards, building codes, and for instituting certification programs.

\subsubsection{Scope and Objectives}

The specific objective of this task is coordination of the Photovoltaic Performance Criteria and Test Standards Project, both internally and externally, with national and international standards organizations and with building code organizations. Participation of the project team, including the technology development resources within the photovoltaic program, with the national voluntary consensus standards community will be emphasized.

\subsubsection{Approach}

The PC/TS Project will address the following areas:

- Coordination of the Performance Criteria and Test Standards Development Project elements with the other Technology Development and Advanced R\&D projects in the photovoltaic program.

- Coordination of PC/TS Project elements with national and international standards-related activities. This coordination probably will be effected through the ANSI Solar Standards Steering Committee's subcommittee for photovoltaic systems.

- Integration of the project with model code development.

- Review of the interpretation and application of PV performance criteria and test methodologies to promote uniformity. This effort will be particularly important for international markets and the application of international standards. SERI will work with voluntary consensus standards organizations and with the photovoltaic community to minimize conflicts in standards development and to develop mechanisms for interpreting and applying interim performance criteria and consensus standards.

For the time frame of this plan-FY79 through FY82-this task is expected to yield a broader understanding and coordination of project activities with those of the voluntary consensus standards process, mainly through active involvement of project participants on standards and code development committees. No specific milestones are identified with this task; it is a continuous process which will extend beyond the period covered by this planning document. 


\author{
APPENDIX A \\ THE ROLE AND PURPOSE OF STANDARDS*
}

\title{
INTRODUCTION
}

Standards are one means of solving some of the practical problems that arise in the operation of markets. Standards can simplify transactions and cut costs. They are a means of transmitting information about a product, system, or service. They represent agreement about such issues as sizes, terminology, product grades, or the determination of quality, of ten providing the two functions of information and agreement within the same document. For example, standard lumber sizes (such as the dimensions of a $2 \times 4$ ) provide not only information on the product's size, but also represent agreement as to what sizes will be produced. Because standards can serve these two functions for whole classes of transactions, they preclude the need for individual agreement and information exchange between an individual buyer and an individual seller.

Standards may have both positive and negative effects. These effects can be grouped into three categories: those affecting costs, those which can expand the demand for a product, and those which affect the competition within an industry.

\section{EFFECTS ON PRODUCT COSTS}

Through the use of standards unnecessary grades or product lines can be eliminated, thus decreasing the required level of inventory. Interchangeability of parts can reduce labor, repair, and maintenance costs.

\section{EFFECTS ON THE DEMAND FOR THE PRODUCT}

Carefully written standards can make a new product interchangeable with one already existing. However, new designs or new products may be judged by old standards, which may make design departures difficult. Standards that transmit information concerning a new product can facilitate comparison of the new with the old. The existence of a standardized product can ensure purchasers of a broader supply because the purchaser is not forced to rely upon a single producer. Minimum quality standards are likely to increase consumer confidence in a product. With increased confidence may come increased demand, other factors being equal.

\section{EFFECTS UPON THE COMPETTTVE NATURE OF AN INDUSTRY}

Standards may reduce the effect of brand names and make it easier for new businesses to enter an industry. If products are standardized and that fact results in interchangeabil-ity of products, the potential exists for the market of an individual producer to increase. Standards-writing involves coordination among producers and nonproducers. That coordination may raise such issues as monopolies, price fixing, or antitrust problems but also may reduce the possibility of such issues becoming a reality.

*This appendix is based on material prepartd by the Massachusetts Institute of Technology Energy Laboratory. 
THE ROLE OF THE FEDERAL GOVERNMENT IN STANDARDS DEVELOPMENT FOR NEW TECHNOLOGY

Quality assurance and activities to stimulate standards development in the context of government programs for new technology development must be carefully gauged to bring about the positive effects and to mitigate any negative effects caused by the creation of standards. Standards activity should be designed to raise consumer/user confidence in applications of the new technology and to provide to consumers information for comparing performance and design characteristics. Especially important for emerging technologies-of which solar is one-is that the standards process encourages innovation while stressing such characteristics as performance (including reliability and durability) and safety.

The use of standards, unless prescribed by law or regulations, is voluntary. Incentives for using voluntary standurds exist to the cxtent that not ising them may prove costly to either the producer or the user. Costs associated with developing agreement and information for single transactions may be too high to justify not using standards. Government support for accelerated standards-writing derives from a need to provide the beneficial aspects of standards writing that probably will not emerge from the private sector in time to meet the needs of industry and users or in time to respond to Congressional mandates. 


\section{APPENDIX B \\ THE VOLUNTARY CONSENSUS STANDARDS SYSTEM AND THE DEVELOPMENT OF STANDARDS}

\section{INTRODUCTION}

Most national standards in the United States are produced through a "voluntary" system made up of representatives from government, industry, users, institutions, and individuals. The system is called "voluntary" for two reasons: interested parties participate on a voluntary basis, and the use (or observance) of standards is voluntary-unless the standards have been adopted by legal or regulatory agencies.

In the voluntary consensus standards system, which is characterized by due process, a balance of interests is achieved through the use of strict voting procedures. A chief feature is the protection of the right of dissent. The use of the consensus concept is important in the standards-writing process as a means of ensuring that the standards have widespread acceptance and use. In standards development practice, consensus is achieved when substantial agreement is reached by concerned interests. Standards writing organizations in the United States have well-established procedures to ensure the operation of due process. These procedures may include adequate notice of a proposed standards-writing undertaking to all persons likely to be affected, opportunity for participation of affected interests in meetings, adequate maintenance and distribution of meeting records, timely reports on ballots, attention to minority opinions, and other such requirements.

\section{CONSENSUS STANDARDS ORGANIZATIONS}

The oversight function for the development of voluntary consensus standards is maintained by the American National Standards Institute (ANSI). ANSIs membership includes over $\mathbf{4 0 0}$ organizations, some of which write standards and each of which participates in the process. ANSIs members are organized into committees specific for a technology, to oversee standards development by assigning standards-writing responsibility to its members. Priorities, needs, and schedules are set to ensure that the need for standards is met and that duplication of effort by the various standards-writing organization is eliminated wherever possible. The outcome of these efforts is the development and promulgation of American National Standards.

In November 1978, the ANSI Solar Standards Steering Committee (SSSC) voted to expand its scope to include the development of standards for photovoltaics. Pending approval by the ANSI Executive Standards Council, the SSSC will assume oversight responsibility for photovoltaic standards development by the voluntary consensus standards community. Two organizational members of ANSI, the American Society for Testing and Materials (ASTM) and the Institute for Electrical and Electronics Engineers (IEEE), have particular interest in the development of photovoltaics standards.

ATSM Committee E-44 on Solar Energy Conversion was organized in June 1978. The scope of subcommittee E44.09 is the development of standards for photovoltaics within the ASTM charter. This subcommittee is one of several groups that may adopt PV performance criteria and test methodologies developed according to the plan outlined in this report. The IEFE Standards Board is presently reviewing-within the various IEEE 
Societies-the appropriate committees that will act on particular aspects of photovoltaic systems.

Performance criteria and test methodologies developed by this project will be referred to various voluntary consensus groups to undergo development leading to their promulgation as American National Standards. This referral probably will be made by the ANSI SSSC.

The voluntary consensus system is time-consuming; it is a long and difficult process to achieve both technical excellence and consensus. This project plan is not intended to write standards; it is intended to accelerate the work of the voluntary consensus system by concentrating efforts and resources directly on the development of performance criteria and test methodologies for photovoltaics.

\section{TYPES OF STANDARDS}

Not all standards are voluntary consensus standards. Within the standards-writing community, five kinds of standards are developed; the principal difference among them is the degree of consensus achleved in the standards-devclopment process. These standards maybe categorized as:

- Company Standards - Consensus is among the employees of a given organization (principally within such departments as design, development, production, and purchasing).

- Industry Standards - Consensus is among the companies within a given industry. Standards are typically developed by a trade association.

- Professional Standards - Consensus is among the individual members of a given profession. Standards are typically developed by a professional society.

- Government Stundards - Consensus is among the employees of a government agency or depurtinent.

- Voluntary Consensus Standards Consensus is among the several elements of the community having an interest in the development and/or use of the standards including producers, users, and those representing the general interest, all of whom may participate actively in standards-writing committees.

\section{PERPORMANCB AND PRESCRIPTIVE STANDARDS}

It is important to note the difference between performance and prescriptive standards. Prescriptive standards are specific in terms of details of usage or design, whereas performance standards cite objectlves or cunditions to be accomplished.

An example of a prescriptive requirement is a specification for timber wall framing-it shall be $2 \times 4$ studs on 16-in. centers. A performance standard would be that the wall system be designed to specified loading and deformation criteria. This allows the innovative designer freedom to select the materials and other cunstruction details.

Articulating requirements in terms of performance rather than in a prescriptive manner will help to prevent the foreclosure of innovation in a technology. Stringent or narrow definitions can preclude innovative steps. The concept of performance standards will be applied as consistently as possible in the photovoltaic PC/TS project. 


\section{APPENDIX C \\ GLOSSARY OF GENERAL DEFINITIONS \\ FOR \\ PHOTOVOLTAIC SUBSYSTEMS HIERARCHY}

FIELD-the aggregate of all solar arrays transmitting power to a given solar power system.

SUBFIELD-a group of arrays associated by a distinguishing feature such as field geometry, electrical interconnection, or power conditioning module.

ARRAY - an assembly of modules or panels with self-sufficient supporting structure, usually field assembled and wired.

PANEL-a shippable assembly of modules (usually two or more) fastened in a supporting framework. A panel may consist of a single module. Panels are usually factory assembled and wired.

MODULE-a functional assembly of solar cells and other components having internal interconnection and external electrical terminals.

COMPONENT-Materials and piece-parts which are used in the fabrication of modules such as encapsulants, solar cells, and electrical connectors.

RECEIVER-the component designed to operate under concentrated sunlight, incorporating the concentrator cell assembly and providing thermal energy removal.

CONCENTRATOR CELL ASSEMBLY-the smallest complete assembly of solar cell(s) designed to generate DC power under concentrated terrestrial sunlight.

SOLAR CELI-the basic photovoltaic device which generates electricity when exposed to sunlight. 


\section{APPENDIX D}

\section{COORDINATING COUNCH MEMBERS}

NAMB

Charles Backus

Drew Bottaro

Ron Diamond

Steve Forman

R. G. Harris

Gary Jones

William Kaszeta

James M. Marler

William Masters

Robert McGinnis

Michael Merchant

Edward Passerini

Steve Patrick

David Redfield

Donald R. Roberts

Ron Ross

Joan Shorey

George Storti

A. M. Wilson

William Yerkes

Gene Zerlaut

\section{ORGANZATION}

Arizona State University MIT/Energy Laboratory Optical Coating Laboratory, Inc. MIT/Lincoln Laboratory Under writers Laboratories Sandia Laboratory SES, Inc. General Electric Co. ACUREX Solar Energy Industries Assn. MCM Enterprises University of Alabama Wyle Laboratories IEEE Westinghouse Electric Corp. Jet Propulsion Laboratory Solar Lobby Solarex Corporation Electronic Industries Assn. ARCO Solar, Inc. ASTM 


\section{APPENDIX E}

\section{SUBCOMMTTTEE MEMBERS}

PV SUBSYSTEMS SUBCOMMITTEEE (Formerly Performance Criteria)

\section{NAME}

Tom Anderson

R. Vail Bontecou

Drew Bottaro

William L. Crabtree

Alan Hoffman

Steve Hogan

Gary Jones

Robert Losey

Leonard Magid

Michael C. Merchant (Chairman)

Gary Nuss

Steve Patrick

Ron Ross

Steven B. Sacco

Harry Schafft

Joan Shorey

Gene Zerlaut

Harry S. Zwibel

\section{ORGANIZATION}

Desert Sunshine Exposure Tests Bontecou Associates MIT/Energy Laboratory Marshall Space Flight Center Jet Propulsion Laboratory Solar Energy Research Institute Sandia Laboratory Wyle Laboratories DOE-PV Systems Branch MCM Enterprises

Solar Energy Research Institute Wyle Laboratories Jet Propulsion Laboratory MIT/Lincoln Laboratory National Bureau of Standards Solar Lobby ASTM

New Mexico Solar Energy Institute

\section{RELIABLITY/DURABILTY SUBCOMMITTEE}

William L. Crabtree

Ken Davidson

Mo Forestieri

Steve Foreman

Alan Hoff man

Steve Hogan

William Kaszeta

Gary Nuss

Steve Patrick

Ron Ross

B. D. Shafer

Joseph Wise

Gene Zerlaut (Chairman)
Marshall Space Flight Center Motorola, Inc.

NASA-Lewis Research Center MIT/Lincoln Laboratory Jet Propulsion Laboratory Solar Energy Research Institute SES, Inc.

Solar Energy Research Institute Wyle Laboratories Jet Propulsion Laboratory Sandia Laboratory Air Folce AERO Prop. Lab ASTM 
Daryl Damster

Edward H. Ernst

William Feero

E. E. Landsman

Robert Losey

Hans Meyer

A. R. Miner

Roy L. Pickrell

Walt Pijawka

Dietrich J. Roesler

Robert Sandcre

Harry Schafft (Chairman)

Paul Sutton

Lloyd H. Vick, Jr.

Jerry Watkins

\section{STORAGE SUBCOMMITTEE}

James Arnett

John J. Barghusen

Dick DeBlasio (Chairman)

E. Michael Henry

Al Landgrebe

Frank Malaspina

Alan Milner

Steve Patrick

Calvin B. Rogers

William Spindlor

\section{SAFETY SUBCOMMITTEE}

James Amett

Dick DeBlasio

Ron Diamond

Steve Forman (Chairman)

Mo Forestieri

Willism Garrisnn

Larry Kazmerski

Paul Sutton

D. R. (Bob) Smith
Gibbs \& Hill, Inc.

General Electric Co.

DOE-Electric Energy Systems

MIT/Lincoln Laboratory

Wyle Laboratories

Windworks, Inc.

MIT/Lincoln Laboratory

NASA-Lewis Research Center

General Electric Co.

DOE-Electric Energy Systems

Motorola, Ine.

National Bureau of Standards

Jet Propulsion Laboratory

New Mexico State University

Solar Energy Research Institute

Jet Propulsion Laboratory

Argonne National Laboratories

Solar Energy Research Institute

TEAM

DOE-Storage Branch

$\mathrm{ESB} / \mathrm{Wisco}$, Inc.

MIT/Lincoln Laboratory

Wyle Laboratories

Sandia Laboratories

EPRI

Jet Propulsion Laboratory

Solar Energy Research Institute

Optical Coating Laboratory, Inc. MIT/Lincoln Laboratory

NASA-Lewis Research Center

Wyle Laboratories

solar Eneryy Research Institutc Jet Propulsion Laboratory

Sandia Laboratory 


\section{APPENDIX $\mathbf{F}$ \\ TASK GROUP STEERING COMMITTE AND TASK GROUPS}

TASR GROUP STEERING COMMITTEE

\section{NAME}

Herbert Davis

Dick DeBlasio (Chairman-Steering Comm.)

Steve Forman (Chairman-Task Group \#2)

Steve Hogan

Leonard Magid

Robert McGinnis

Hal Post (Chairman-Task Group \#3)

Ron Ross (Chairman-Task Group \#1)

Harry Schafft

TASK GRODP NO. 1-PV SUBSYSTEMS

Henry Curtis

Ron Diamond

Alan Hoff man

Steve Hogan

Bruce Larson

Steve Patrick

Gene Ralph

Ron Ross (Chairman)

B. D. Shafer

Harry Schafft

Neal Shepard

Byard D. Wood

Gene Zerlaut

\section{ORGANIZATION}

Jet Propulsion Lab/Lead Center Solar Energy Research Institute MIT/Lincoln Laboratory

Solar Energy Research Institute. DOE-Photovoltaic Systems Branch

Solar Energy Industries Assn. Sandia Laboratory Jet Propulsion Laboratory National Bureau of Standards

NASA/Lewis Research Center

OCLI

Jet Propulsion Laboratory

Solar Energy Research Institute

Motorola, Inc.

Wyle Laboratories

Spectrolab, Inc.

Jet Propulsion Laboratory

Sandia Laboratory

National Bureau of Standards

General Electric Co.

Arizona State University

Desert Sunshine Exposure T'ests

\section{TASK GROUP NO. 2-OTHER SUBSYSTEMS (POWER CONDITIONING, CONTROLS, STORAGE AND CABLING)}

John Barghusen

Jay Chamberlain

Clint Cristianson

Ralph Ferraro

Kay Firor

Steve Forman (Chairman)

Jack Harris

Jack Helfrich

Leif Isaksen

David Klein

Stanley Krauthamer

E. E. Liandsman

Frank Malaspina
Argonne National Laboratories Sandia Laboratories Argonne National Laboratories EPRI

Solar Energy Research Institute MIT/Lincoln Laboratory Texas Electric Service MIT/Lincoln Laboratory Systems Control, Inc. MIT/Lincoln Laboratory Jet Propulsion Laboratory MIT/Lincoln Laboratory ESB/Wisco 
TAKS GROUP NO. 2-OTHER SUBSYSTEMS (POWER CONDITONING, CONTROLS, STORAGE AND CABLING) - Continued

Hans Meyer

Alan Millner

Robert Smith

George O'Sullivan

Walter Stolte

Joseph Vivirito

Jerry Watkins

Gordon Young

\section{TASK GROUP NO. 3-GYSTBMS}

Ronald Cull

Gary Jones

Hal Macomber

Edward Mehalick

Phil Pierce

Paul Pittman

Hal Post (Chairman)

Arthur Rudin

Miles C. Russell

Chandler Schrock

Elmer Streed

Russell S. Sugimura
Windworks, Inc.

MIT/Lincoln Laboratory

Sandia Laboratories

Abacus Controls

Bechtel National, Inc.

United Technologies

Solar Energy Research Institute

Ford, Bacon \& Davis

NASA/Lewis Research Center

Sandia Laboratory

TEAM

General Electric Co.

Solar Energy Research Institute

Westinghouse Electric Corp.

Sandia Laboratories-

Albuquerque

ARCO Solar, Inc.

MIT/Lincoln Laboratory

Solar Energy Research Institute

National Bureau of Standards

Jet Propulsion Laboratory 